\title{
Pertanggungjawaban Ahli Waris Notaris sebagai Pejabat Umum atas Akta Notaris yang Menimbulkan Kerugian Para Pihak
}

\author{
Anang Ade Irawan \\ Brawijaya University, Indonesia \\ adeanang.aa@gmail.com
}

\author{
A. Rachmad Budiono \\ Brawijaya University, Indonesia \\ rachmad.budiono@ub.ac.id \\ Herlin Wijayati \\ Brawijaya University, Indonesia \\ gsal15@ub.ac.id
}

\begin{abstract}
This article discusses the provision of Article 65 of Notary Law (UUJN) which contains the unclear time limit of the notary's responsibility in performing his duties as a public official. The article does not provide explicit explanations to the extent to which the notary no longer holds the responsibility after termination or death to the authentic deeds made. The purpose of this study is to know, identify and analyze the form of accountability of notary heirs as general officials on notarial deeds that cause harm to the parties. By using normative research, there are research results among others. First, based on the theory of fautes personalles, the theory which states that losses to third parties are imposed on officials who because of their actions have caused harm. Second, according to the theory of inheritance that becomes the object of the estate is a wealth in the sense of assets and liabilities. Unlawful acts of civil law are per-artificial wrong done by individuals, so it can not be associated with war-isnya experts.
\end{abstract}

KEYWORDS: Responsibility, Notary Public Notary, Public Official, Notary Deed.

Copyright $\odot 2018$ by Author(s)

This work is licensed under a Creative Commons Attribution-ShareAlike 4.0 International License. All writings published in this journal are personal views of the authors and do not represent the views of this journal and the author's affiliated institutions.

\section{HOW TO CITE:}

Irawan, Anang Ade, A. Rachmad Budiono \& Herlin Wijayati. "Pertanggungjawaban Ahli Waris Notaris sebagai Pejabat Umum atas Akta Notaris yang Menimbulkan Kerugian Para Pihak” (2018) 5:2 Lentera Hukum 34l-358.

Submitted: February 19, 2018 Revised: April 28, 2018 Accepted: May 14, 2018 


\section{PENDAHULUAN}

Hukum sebagai kaidah sosial, bukan berarti bahwa pergaulan antar manusia dalam masyarakat hanya diatur oleh hukum. Kehidupan manusia dalam masyarakat selain dipedomani moral manusia itu sendiri, diatur pula oleh agama, kaidah-kaidah sosial, kesopanan, adat istiadat dan kaidah-kaidah sosial lainnya. Terdapat hubungan yang erat antara hukum dan kaidah-kaidah sosial lainnya, di mana saling memperkuat satu sama lain. Hukum yang berlaku biasanya tidak dipergunakan secara bijak oleh manusia, sehingga menimbulkan benturan dengan kaidah-kaidah sosial lainnya. Menurut Utrecht, hukum merupakan himpunan petunjuk-petunjuk hidup serta tata tertib suatu masyarakat dan harus ditaati oleh anggota masyarakat yang bersangkutan. Sehingga, ketika norma-norma terebut menciptakan berbagai masalah hukum seperti mafia peradilan, korupsi dan gugatan keperdataan seolah menjadi hal yang biasa dalam penegakan hukum di Indonesia.

Peraturan perundang-undangan dibuat berdasarkan Undang-Undang Dasar Negara Republik Indonesia Tahun 1945 (UUD 1945) dan Pancasila yang merupakan dasar pijakan dalam menjamin perlindungan dan kepastian hukum bagi setiap masyarakat. Hal ini sebagai upaya negara guna meminimalisir dan mengatasi berbagai masalah yang timbul dalam masyarakat. Di samping itu, harus ada campur tangan lembaga kemasyarakatan yang memberikan pengawasan terhadap pelaksanaan hukum agar berjalan dengan baik, sehingga mampu menciptakan keamanan dan ketertiban dalam masyarakat. Melalui lembaga kemasyaraatan yaitu Lembaga Kenotariatan, lembaga ini bergerak dalam bidang keperdataan khususnya dalam membuat alat pembuktian yang ada di Indonesia. Lembaga ini dibentuk sebagai wujud dalam melihat kebutuhan masyarakat yang menginginkan suatu alat pembuktian dalam bidang keperdataan. $^{2}$

Sebagai profesi jabatan yang mulia, notaris harus diemban dengan rasa tanggung jawab besar. Sehubungan dengan hal tersebut, seorang notaris harus mengangkat sumpah sebelum menjalankan profesi jabatan sebagaimana Undang-Undang Nomor 2 Tahun 2014 tentang Jabatan Notaris (UUJN) dan Kode Etik Profesi Notaris. Tugas utama notaris yaitu membuat alat bukti otentik yang berupa akta notaris dan menjalanan tugas di luar peraturan perundang-undangan, misalnya dalam pendaftaran fidusia dan pengurusan serta pengesahan badan hukum. ${ }^{3}$

Akta yang dibuat notaris menguraikan secara otentik mengenai semua penetapan, perjanjian dan perbuatan yang disaksikan oleh para penghadap dan saksi-saksi. ${ }^{4}$ Dalam suatu akta otentik memuat suatu perjanjian antara pihak-pihak yang menghadap notaris. Syarat sahnya perjanjian menurut hukum diatur dalam Pasal 1320 Kitab

1 Mochtar Kusumaatmadja, Fungsi dan Perkembangan Hukum dalam Pembangunan Nasional, Lembaga Penelitian Hukum dan Kriminologi Fakultas Hukum Universitas Padjararan, Penerbit Bina Cipta, Bandung, hlm. 2.

G.H.S. Lumban Tobing, Peraturan Jabatan Notaris, Erlangga, Jakarta, 1999, hlm. 2.

Herlien Budiono,"Pertanggungjawban Notaris Berdasarkan Undang-Undang No. 30 Tahun 24 (Dilema Notaris diantara Negara, Masyarakat dan Pasar", Renvoi, Jakarta, 2005, hlm. 33.

4 Wawan Tunggal Alam, Hukum Bicara Kasus-kasus dalam Kehidupan Sehari-hari, Milenia Populer, Jakarta, 200l, hlm. 85. 
Undang-Undang Hukum Perdata (KUH Perdata). Suatu akta dapat dikatakan batal demi hukum apabila akta tersebut tidak memenuhi syarat obyektif yaitu tidak adanya suatu hal tertentu dan tidak ada kausa yang halal dari perjanjian tersebut. Dengan kata lain, perjanjian yang termuat dalam suatu akta bisa dianggap tidak pernah ada dan tidak dapat mengikat para pihak.

Akta yang dibuat notaris pada dasarnya memiliki kekuatan pembuktian sempurna. Berbeda dengan akta di bawah tangan yang dibuat sendiri oleh pihak-pihak yang berkepentingan tanpa bantuan pejabat umum. ${ }^{5}$ Akta otentik merupakan produk notaris yang sangat dibutuhkan masyarakat demi terciptanya suatu kepastian hukum. Akta otentik sebagai alat bukti yang terkuat dan terpenuh, memiliki peran penting dalam hubungan hukum di masyarakat, baik hubungan bisnis/kerjasama, kegiatan di bidang pertanahan, perbankan, kegiatan sosial dan dalam kebutuhan hidup lainnya.

Terlepas dari tugas profesi notaris yang berwenang membuat akta notaris, pemberian kewenangan pada notaris akan menimbulkan konsekuensi hukum dengan lahirnya beban tanggung jawab hukum. Konsekuensi ini melahirkan beban tanggung jawab hukum yang sangat besar guna memberikan suatu kepastian hukum dalam masyarakat. Indonesia merupakan negara hukum, artinya kedaulatan tertinggi berada di tangan rakyat, peran pemerintah hanya sebagai penyelenggara urusan negara dalam menjaga kepastian hukum dan ketertiban di masyarakat. Dengan demikian, notaris yang diangkat oleh negara, secara tidak langsung bertanggung jawab dalam memberikan kepastian hukum di masyarakat. ${ }^{6}$

Pasal 65 UUJN tidak diatur secara jelas kapan batas waktu pertanggungjawaban seorang notaris. Sehingga dalam hal notaris tersebut meninggal dunia, masih dimungkinkan untuk bertanggung jawab bilamana muncul gugatan dari pihak yang merasa dirinya dirugikan. UUJN tidak memberikan penjelasan secara eksplisit mengenai tanggung jawab notaris setelah berakhirnya masa jabatannya maupun meninggal dunia terhadap akta otentik yang dibuatnya. Pasal terebut tidak menjelaskan sejauh mana batas waktu tanggung jawab notaris yang telah pensiun. Akan tetapi, hanya menjelaskan bahwa notaris bertanggung jawab terhadap akta tersebut, meskipun telah berpindah tangan kepada pemegang protokol notaris. Sehingga menimbulkan ketidakjelasan dan menimbulkan masalah di kalangan notaris. Tidak adanya kejelasan dalam Pasal 65 UUJN terhadap pembatasan tanggung jawab notaris setalah purna tugas, baik karena pensiun maupun meninggal dunia terhadap akta yang dibuatnya menimbulkan kekaburan norma dalam UUJN. Kekaburan yang dimaksud adalah tidak dijelaskan secara jelas mengenai batas waktu tanggung jawab notaris setelah berakhir masa jabatan, sehingga sampai saat ini memaknai bahwa notaris bertanggung jawab terhadap akta yang dibuat walaupun telah berhenti menjabat harus bertanggung jawab seumur hidup.

Taufik Makarao, Pokok-pokok Hukum Acara Perdata, PT. Rineka Cipta, Jakarta, 2004, hlm. 100.

Bunyi Pasal 65 UUJN “ Notaris, Notaris Pengganti, dan Pejabat Sementara Notaris bertanggung jawab atas setiap Akta yang dibuatnya meskipun Protokol Notaris telah diserahkan atau dipindahkan kepada pihak penyimpan Protokol Notaris." 
Dalam Putusan Nomor : 440/PDT.G/2013/PN.JKT.PST, tanggung jawab notaris tidak berhenti meskipun notaris telah meninggal dunia. Kemudian yang menjadi polemik, tanggung jawab notaris yang telah meninggal apakah dapat dialihkan kepada notaris pengganti sebagai penerima protokol notaris, ataukah kepada ahli waris yang meninggal dunia. Berdasarkan hak dan kewajiban terhadap harta peninggalan yang ia terima, hak ahli waris adalah menerima harta warisan yang menjadi bagiannya. Sebaliknya ahli waris pun mempunyai beberapa kewajiban, yaitu berkewajiban mengurus biaya perawatan jenazah, segala hutang pewaris dan sebagainya. Sehingga bila melihat hak dan kewajiban sebagai ahli waris, konteks hukum waris berkaitan dengan harta kekayaan, bukan berkaitan dengan perpindahan tanggung jawab jabatan. Pentingnya mengenai kejelasan pengaturan dalam UUJN mengenai pertanggungjawaban notaris yang meninggal dunia terhadap gugatan yang menimbulkan kerugian dalam sebuah akta notaris menjadi sebuah keharusan guna menjamin ketertiban dan kepastian hukum.

Adapun latar belakang kasus yang telah penulis uraikan di atas terjadi suatu permasalahan hukum sehingga perlu dikaji lebih dalam mengenai apakah ahli waris notaris bertanggung jawab sebagai pejabat umum atas akta notaris yang menimbulkan kerugian bagi para pihak. Selain itu, penulis juga ingin mengetahui, mengidentifikasi dan menganalisis bentuk pertanggungjawaban ahli waris notaris sebagai pejabat umum terhadap akta notaris yang menimbulkan kerugian bagi para pihak.

Berdasarkan uraian di atas, pembahasan artikel ini terdiri dari tiga bagian. Bagian pertama menguraiakan tentang kedudukan notaris sebagai turut tergugat dalam perkara perdata. Bagian kedua meninjau mengenai akibat hukum dari akta notaris yang memuat keterangan palsu dalam suatu perkara perdata. Bagian ketiga mengevaluasi mengenai tanggung jawab ahli waris notaris sebagai pejabat umum atas akta notaris yang menimbulkan kerugian bagi para pihak.

\section{PEMBAHASAN}

A. Kedudukan Notaris sebagai Turut Tergugat dalam Perkara Perdata terhadap Akta yang Menimbulkan Kerugian Bagi Para Pihak

Notaris sebagai pejabat umum yang menjalankan profesi pelayanan hukum kepada masyarakat, dalam melaksanakan tugasnya perlu mendapatkan perlindungan dan jaminan demi tercapainya kepastian hukum. Selain itu, notaris mampu memberi jaminan kepastian, ketertiban, dan perlindungan hukum dibutuhkan alat bukti tertulis yang bersifat otentik mengenai keadaan, peristiwa, atau perbuatan hukum yang diselenggarakan melalui jabatan tertentu.

Notaris mempunyai tempat kedudukan di daerah kabupaten atau kota, yaitu kedudukan yang berkenaan dengan pengangkatan sebagai notaris oleh kantor Kementerian Hukum dan Hak Asasi Manusia Republik Indonesia (Kemenkumham). Dengan demikian, dalam cakupan wilayah kerja, notaris mempunyai wilayah jabatan meliputi seluruh wilayah provinsi dari tempat kedudukannya. Notaris wajib 
mempunyai satu kantor, yaitu di tempat kedudukannya. Notaris tidak berwewenang secara teratur menjalankan jabatan di luar tempat kedudukannya. Kedudukan notaris sebagai pejabat pembuat akte otentik disebutkan dalam Pasal 2 angka 1 UUJN, yang menyebutkan notaris adalah pejabat umum yang berwewenang untuk membuat akte otentik dan memiliki kewenangan lainnya sebagaimana dimaksud dalam UUJN atau berdasarkan undang-undang lainnya.

Kewenangan notaris dalam pembuatan akta otentik melahirkan konsekuensi munculnya tanggung jawab yang sangat besar terhadap akta yang dibuatnya. Pada suatu kasus notaris dimungkinkan duduk sebagai turut tergugat atas keotentikan akta yang yang dibuatnya, misalnya pada putusan perdata Nomor 1005/Pdt.G/2014/PN.SBY, Notaris Arief Hidayat duduk sebagai turut tergugat dalam sengketa perdata antara Stevanus Budianto sebagai penggugat melawan Agus Hariyanto sebagai tergugat. Dalam perkara tersebut penggugat meragukan keotentikan akta yang dibuat oleh Notaris Arief Hidayat karena penggugat merasa belum pernah menandatangani akta jual beli yang sah menurut hukum. Namun tergugat sudah melakukan upaya hukum yaitu telah melakukan proses balik nama sertifikat di Kantor Pertanahan Kota Surabaya.

Berdasarkan kasus di atas, seorang Notaris/PPAT dapat didudukkan sebagai turut tergugat dalam suatu gugatan perdata terhadap objek sengketa yang telah dia buat akta peralihan haknya. Notaris tidak punya kepentingan hukum langsung terhadap perkara yang diajukan, hanya berkedudukan sebagai pelengkap saja. Notaris/PPAT tersebut dijadikan turut tergugat agar gugatan menjadi lengkap, sehingga dia dapat dimohonkan agar tunduk dan taat terhadap putusan. Maksimal pengadilan menyatakan bahwa akta yang dia buat tidak mempunyai kekuatan hukum mengikat.

Istilah turut tergugat tidak akan dijumpai dalam peraturan perundang-undangan, namun muncul dalam praktek pengadilan. Kebutuhan hukum meniscayakan subyek hukum turut tergugat, dia tidak memenuhi kriteria legal standing sebagai penggugat maupun tergugat dalam suatu perkara perdata. Namun kehadirannya dibutuhkan, bahkan tanpa dia terkadang perkara dinyatakan kurang pihak dan berakhir NO (niet ontvenkelijke verklaard). Meskipun eksistensi turut tergugat dalam peraturan perundangundangan belum diatur, namun telah banyak pakar/ahli hukum yang membahasnya.

Pakar hukum yang mengupas perihal turut tergugat diantaranya adalah Retnowulan Sutantio dan Iskandar Oerip Kartawinata. Keduanya menggariskan bahwa dalam praktek perkataan turut tergugat dipergunakan bagi orang-orang yang tidak menguasai barang sengketa atau tidak berkewajiban untuk melakukan sesuatu, hanya demi lengkapnya suatu gugatan harus diikutsertakan. Mereka dalam petitum hanya sekedar dimohonkan agar tunduk dan taat terhadap putusan hakim. ${ }^{7}$ Dari rumusan tersebut, diperoleh tiga kriteria bahwa turut tergugat adalah orang/pihak yang tidak menguasai objek sengketa, tidak berkewajiban melakukan sesuatu dan diikutsertakan untuk melengkapi gugatan.

Retnowulan Sutantio dan Iskandar Oerip Kartawinata. Hukum Acara Perdata dalam Teori dan Praktek, Mandar Maju Bandung, 1995, hlm. 2. 
Berawal dari kriteria turut tergugat di atas, ternyata melahirkan kedudukan turut tergugat yang tidak tunggal. Ada turut tergugat yang benar-benar pasif, baik dalam proses persidangan maupun setelah putusan dijatuhkan dan memiliki kekuatan hukum tetap. Dalam proses persidangan, meskipun mereka tidak datang tidak mempengaruhi jalannya persidangan dan setelah putusan dijatuhkan juga tidak terkait langsung dalam proses pelaksanaanya. Akan tetapi, ada turut tergugat yang harus mengambil peran dalam persidangan dan terlibat dalam proses selanjutnya sampai eksekusi.

Pembatalan akta Notaris/PPAT melalui putusan pengadilan, bukan hanya karena akibat dari kesalahan atau kelalaian Notaris/PPAT dalam membuat akta. Tetapi juga dapat disebabkan oleh kesalahan atau kelalaian para pihak yang saling mengikatkan diri dalam akta tersebut, sehingga dengan kesalahan atau kelalaian menyebabkan adanya gugatan dari salah satu pihak. Di dalam proses perdata, tidak jarang seorang Notaris/PPAT berada pada kedudukan sebagai turut tergugat yang diberikan sebagai upaya yang dipaksakan. Karena di dalam akta notariil khususnya PartijActe yang kemudian menjadi alat bukti untuk perkara perdata, Notaris/PPAT tidak terlibat bahkan dilarang oleh UUJN terlibat dalam suatu perbuatan hukum sebagaimana yang diterangkan dalam akta notariil yang diresmikannya. Keterlibatan Notaris/PPAT hanya sebatas merumuskan perbuatan hukum para pihak ke dalam aktanya selanjutnya meresmikan akta tersebut. Dipaksakannya mendudukkan Notaris/PPAT sebagai turut tergugat merupakan upaya untuk memaksa Notaris/PPAT membuatkan keterangan seputar aktanya yang sekarang menjadi alat bukti dalam proses peradilan. ${ }^{8}$ Misalnya, pada perkara kewarisan kedua kemungkinan itu bisa terjadi, yakni ada turut tergugat pasif dan turut tergugat aktif, baik berdiri sendiri atau bersama-sama dalam suatu perkara.

Dalam sengketa harta bersama terbuka juga kemungkinan adanya turut tergugat. Turut tergugat dalam hal ini biasanya instansi terkait, seperti perbankan, PPAT, Notaris dan Badan Pertanahan Nasional (BPN). Pihak perbankan sering didudukkan sebagai turut tergugat dikarenakan harta bersama kedua belah pihak disimpan di bank, baik berupa tabungan, deposito atau giro. Atau karena kedua belah pihak punya kredit atau pembiayaan di bank. Tidak ditariknya bank sebagai tergugat karena sesungguhnya bank tidak menguasai objek sengketa, hanya menerima titipan sementara atau karena kedua pihak mempunyai tanggungan bersama di bank. Walaupun uang di bank milik nasabah tapi nasabah tidak boleh semaunya mengambil uangnya, tentu ada aturan khusus sesuai kesepakatan yang ditanda tangani. Turut tergugat berikutnya dalam sengketa harta bersama biasanya PPAT.

Notaris atau Kantor Pertanahan. PPAT atau notaris ditarik sebagai turut tergugat terkait dengan akta peralihan hak yang telah mereka buat terhadap objek sengketa. Hal yang sama berlaku bagi Kantor Pertanahan terhadap objek sengketa yang telah diterbitkan sertifikat tanahnya. Mereka dituntut tunduk pada putusan pengadilan manakala akta/sertifikat yang mereka keluarkan dinyatakan tidak mempunyai kekuatan hukum atau tidak mengikat

8 Djoko Sukisno, Pengambilan Fotocopy Minuta Akta dan Pemanggilan Notaris, Mimbar Hukum vol. 20 nomor 1, 2008, hlm. 52. 


\section{B. Akibat Hukum Terhadap Akta Notaris yang Memuat Keterangan Palsu dalam Sengketa Perdata}

Pada dasarnya hakim tidak dapat membatalkan akta notaris apabila pembatalan akta tersebut tidak dimintakan kepadanya, karena hakim tidak boleh memutuskan yang tidak dimintakan. Pembatalan akta adalah kewenangan hakim perdata, yakni dengan mengajukan gugatan secara perdata ke pengadilan. Apabila dimintakan pembatalan akta oleh pihak yang dirugikan maka akta notaris tersebut dapat dibatalkan oleh hakim melalui sebuah putusan pengadilan apabila ada bukti lawan. Menurut Yahya Harahap, ditinjau dari segi hukum, pengertian putusan batal demi hukum berakibat putusan yang dijatuhkan, yaitu dianggap "tidak pernah ada" atau never existed sejak semula; putusan yang batal demi hukum tidak mempunyai kekuatan dan akibat hukum; dengan demikian putusan yang batal demi hukum sejak semula putusan itu dijatuhkan sama sekali tidak memiliki daya eksekusi atau tidak dapat dilaksanakan. ${ }^{9}$ Jadi putusan yang batal demi hukum adalah putusan yang sejak semula dijatuhkan, putusan itu dianggap tidak pernah ada, tidak mempunyai kekuatan dan akibat hukum, serta tidak memiliki daya eksekusi.

Menurut Pitlo ${ }^{10}$, akibat pembatalan oleh hakim berlaku mundur/surut sampai pada saat tindakan itu Dilakukan. Sehingga dengan pembatalan itu seakan-akan tidak pernah ada tindakan seperti itu. Setelah pernyataan batal oleh hakim, maka keadaannya menjadi sama dengan yang batal demi hukum. Berbeda halnya jika pembatalan dilakukan dengan kesepakatan para pihak. Sepakat pembatalan para pihak (secara intern) tidak dapat memberikan efek seperti itu, sebab sepakat untuk membatalkan suatu perjanjian yang telah dibuat, hanya menjangkau masa yang akan datang saja. Artinya untuk selanjutnya perjanjian yang disepakati batalnya itu, tidak akan menimbulkan perikatan-perikatan baru.

Berdasarkan hukum perjanjian, batal demi hukum (nietig) merupakan istilah untuk perjanjian yang tidak memenuhi syarat objektif (hal tertentu dan kausa yang halal). Sedangkan dapat dibatalkan dimaksudkan untuk perjanjian yang tidak memenuhi syarat subjektif (kesepakatan dan kecakapan). Berbeda dengan keadaan yang dapat dibatalkan, keadaan batal demi hukum tidak memerlukan permintaan dari para pihak. Walaupun begitu, menurut R. Subekti, jika suatu perjanjian sudah tidak memenuhi syarat objektif, namun ada yang menggugat, maka hakim diwajibkan karena jabatannya, menyatakan tidak pernah ada suatu perjanjian atau perikatan. 11

Adapun yang dapat diklasifikasikan sebagai potensi konflik dalam akta sehingga dapat menimbulkan kerugian dan kehilangan keaslian akta, dapat disebabkan karena tidak terpenuhinya salah satu syarat untuk membuat akta yang telah ditentukan oleh

\footnotetext{
9 Yahya Harahap, Pembahasan, Permasalahan dan Penerapan KUHAP: Pemeriksaan Sidang Pengadilan, Banding, Kasasi, dan Peninjauan Kembali, Sinar Grafika,Jakarta, 2000, hlm. 385.

10 J. Satrio, Hukum Perikatan tentang Hapusnya Perikatan Bagian 2, PT. Citra Aditya Bakti, Bandung, 1996, hlm. 174.

Il R. Subekti, Hukum Perjanjian, Intermasa, Jakarta, 2005, hlm. 22.
} 
Undang-undang. Misalnya tidak terpenuhinya Pasal 1320 KUHPerdata. Menurut Pasal 1320 KUHPerdata, untuk menentukan sahnya suatu perjanjian harus memenuhi empat syarat yaitu ${ }^{12}$ kesepakatan mereka yang mengikatkan dirinya, kecakapan untuk membuat suatu perikatan, suatu hal tertentu dan suatu sebab yang halal.

Syarat pertama berkaitan dengan kesepakatan yang mengikatkan diri. Kata sepakat dari mereka yang mengikatkan diri mengandung pengertian para pihak untuk saling mengikatkan diri satu sama lain dalam suatu perjanjian. Artinya para pihak harus sepakat mengenai hal-hal pokok dari perjanjian yang diadakan itu. Mengetahui sah atau tidaknya suatu perjanjian telah ditentukan oleh Pasal 1321 KUHPerdata yang menyatakan bahwa tidak dianggap sah suatu kesepakatan, jika kesepakatan itu diberikan karena salah pengertian atau kekhilafan (dwaling), paksaan (dwang) dan Penipuan.

Syarat kedua berkaitan dengan kecakapan, sahnya suatu perjanjian memerlukan kecakapan dari subyek yang mengadakan perjanjian. Artinya orang yang sudah dewasa dan sehat akal budinya. Pasal 1330 KUHPerdata menyebutkan bahwa tidak cakap untuk membuat suatu perjanjian adalah orang yang belum dewasa artinya orang yang belum dewasa adalah mereka yang belum mencapai umur genap 21 tahun dan tidak lebih dahulu kawin, mereka yang berada di bawah pengampuan artinya Pasal 433 KUHPerdata menyebutkan bahwa mereka yang berada di bawah pengampuan adalah setiap orang dewasa, yang selalu berada dalam keadaan dungu, gelap mara atau terlalu boros, sehingga tidak mampu bertanggungjawab atas kepentingan sendiri karena itu dalam melakukan suatu perbuatan hukum mereka diwakili oleh pengampunya.

Syarat ketiga berkaitan dengan suatu hal tertentu, undang-undang menentukan tentang obyek yang diperjanjikan haruslah dapat ditentukan, paling tidak jenisnya. Hal ini terdapat dalam Pasal 1333 KUHPerdata, menyebutkan bahwa suatu perjanjian harus mempunyai pokok suatu barang yang paling sedikit ditentukan jenisnya. Tidaklah menjadi halangan bahwa jumlah barang tidak tentu, asal saja jumlah itu kemudian dapat ditentukan atau dihitung.

Syarat keempat berkaitan dengan suatu sebab yang halal. Suatu sebab yang halal maksudnya tidak lain daripada perjanjian itu sendiri. Sesuatu yang menyebabkan seseorang membuat suatu perjanjian, pada dasarnya tidak diperdulikan oleh undangundang. Menurut undang-undang suatu sebab yang halal itu apabila tidak bertentangan dan dilarang oleh undang-undang, tidak bertentangan dengan ketertiban umum dan tidak bertentangan dengan kesusilaan umum. Keempat syarat ini merupakan syarat yang harus dipenuhi dalam membuat perjanjian yang sah menurut hukum.

Sebagaimana diketahui bahwa akta notaris menurut Pasal 1870 KUHPerdata adalah dokumen resmi yang dikeluarkan oleh notaris sebagai alat bukti tertulis yang mempunyai kekuatan pembuktian yang mengikat dan sempurna. Ini berarti bahwa masih dimungkinkan dapat dilumpuhkan oleh bukti lawan yakni diajukannya gugatan untuk menuntut pembatalan akta ke pengadilan agar akta tersebut dibatalkan melalui

12 Muhammad Yahya Harahap, Segi-Segi Hukum Perjanjian, Alumni, Bandung, 1986, hlm. 6. 
sebuah putusan pembatalan. Sehingga ketika keluar putusan hakim yang menyatakan sebaliknya, maka perbuatan hukum dianggap tidak pernah ada. Hal ini sejalan dengan pendapat Yahya Harahap, ditinjau dari segi hukum, pengertian putusan batal demi hukum berakibat putusan yang dijatuhkan yaitu dianggap "tidak pernah ada" atau never existed sejak semula, putusan yang batal demi hukum tidak mempunyai kekuatan dan akibat hukum, dengan demikian putusan yang batal demi hukum sejak semula putusan itu dijatuhkan sama sekali tidak memiliki daya eksekusi atau tidak dapat dilaksanakan. ${ }^{13}$. Dengan demikian terhadap pembatalan memang diperlukan suatu putusan oleh hakim.

Berkaitan dengan akta yang mengakibatkan akta tersebut cacat hukum maka notaris mempunyai kewajiban untuk menjelaskan dan menunjukkan akibat dari suatu akta yang tidak memiliki kepastian tanggal dan waktu sehingga menimbulkan kerugian terhadap orang lain. Dikarenakan orang tersebut tidak dapat menggunakan akta tersebut sebagai akta otentik yang memiliki kekuatan pembuktian sempurna. Notaris juga dianggap telah mengetahui akibat dari pembuatan akta cacat hukum, yaitu akan dibatalkan oleh pengadilan dan juga konsekuensi terhadap akta yang dibuatnya tersebut menjadi terdegradasi sehingga penilaian pembuktiannya menjadi akta di bawah tangan.

Dengan demikian, tugas dan kewajiban notaris dalam membuat akta notaris memiliki peluang yang tinggi terhadap kejahatan pemalsuan. Belum lagi pemalsuan yang notabene dilakukan oleh notaris itu sendiri yang kemudian berakibat kerugian bagi pihak yang lainnya. Contoh kerugian bagi pihak yang lainnya adalah apabila seorang pejabat membeli tanah atau rumah saat dia menjabat tetapi akta jual beli dibuat dengan menggunakan tanggal dan waktu sebelum menjabat padahal uang yang digunakan adalah uang negara maka tanah atau rumah tersebut tidak termasuk dalam harta yang diperoleh selama dia menjabat. Sehingga dalam hal ini negara yang mengalami kerugian atas pembuatan akta yang dicatat dalam sela-sela kosong buku daftar akta di antara akta yang telah dicatat dalam buku daftar akta. ${ }^{14}$ Dengan demikian, seorang notaris yang membuat akta cacat hukum dapat digugat atas dasar wanprestasi maupun perbuatan melanggar hukum (onrechtmatige daad). Dalam praktek, gugatan berdasarkan wanprestasi dimasukkan ke dalam gugatan primer sedangkan gugatan berdasarkan perbuatan melawan hukum dimasukkan dalam gugatan subsidair. ${ }^{15}$

Selama tidak dimintakan pembatalan maka perjanjian yang tercantum dalam akta tersebut akan tetap berlaku. Setelah adanya putusan hakim yang berkekuatan hukum tetap atas gugatan penuntutan pembatalan akta tersebut maka akta itu tidak lagi mempunyai kekuatan hukum sebagai alat bukti yang otentik karena mengandung cacat hukum. Maka dalam amar putusan hakim akan menyatakan bahwa akta tersebut batal

13 Yahya Harahap, supra note 9., hlm. 385.

14 Yuli Kristina, Analisis Yuridis terhadap Akta Notaris yang Dicatat dalam Sela-Sela Kosong Di Antara Akta Notaris yang Telah Dicatat Dalam Buku Daftar Akta Notaris, Jurnal Hukum Universitas Brawijaya, 2015, Thesis.

15 Marthalena Pohan, Tanggung Gugat Advokad Dokter dan Notaris, Bina Ilmu, Surabaya, 1985, hlm. 17. 
demi hukum. Memang tidak mudah bagi hakim untuk membuat putusan yang ideal. Maksud putusan yang ideal menurut Gustav Radbruch adalah putusan yang memuat idee des recht, yang meliputi 3 unsur yaitu keadilan (gerechtigkeit), kepastian hukum (rechtsicherheit) dan kemanfaatan (zwechtmassigkeit) ${ }^{16}$. Dengan adanya ketiga tujuan hukum tersebut diharapkan mampu menciptakan penegakan hukum yang dicita-citakan.

Masing-masing tujuan ini memiliki posisi yang telah permanen dalam suatu konstruksi hukum. Kepastian hukum terletak pada pasal-pasal perundang-undangan. Kemanfaatan terletak pada tujuan pasal-pasal tersebut dibuat atau akibat hukum dari suatu putusan pengadilan. Sementara keadilan terletak pada nilai-nilai kehidupan yang ada (living law). Dengan demikian, seringkali adanya benturan antara kepastian hukum dan keadilan, dan tidak jarang seorang hakim yang menemui kondisi seperti itu dalam suatu sengketa yang ditanganinya. Hakim akan memilih salah satu di antara tujuan hukum tersebut dan mengenyampingkan tujuan hukum yang lainnya.

Berlakunya pembatalan akta tersebut adalah berlaku surut yakni sejak perjanjian itu dibuat. Pembatalan terhadap suatu akta otentik dapat juga dilakukan oleh notaris apabila para pihak/penghadap menyadari adanya kekeliruan atau kesalahan yang telah dituang dalam akta tersebut, sehingga timbul keragu-raguan terhadap materiil akta. Dengan demikian, berdasarkan kesepakatan dari para pihak/penghadap, maka akta tersebut dapat dibatalkan oleh notaris.

\section{Tanggung Jawab Ahli Waris Notaris sebagai Pejabat Umum atas Akta Notaris yang Menimbulkan Kerugian bagi Para Pihak}

Notaris dapat dimintakan pertanggungjawaban atas akta otentik yang berakibat batal demi hukum. Pertanggungjawaban yang dapat membebani seorang notaris adalah pertanggungjawaban secara pribadi, yaitu seorang notaris bertanggung jawab terhadap pelanggaran yang dilakukannya sendiri. Apabila akta otentik yang dibuat dihadapan notaris berakibat batal demi hukum dan karenanya para penghadap merasa dirugikan maka notaris wajib mempertanggungjawabkan tindakannya. Seharusnya seorang notaris berhati-hati dan cermat dalam membuat akta. Pengertian tanggung jawab adalah kesadaran yang ada dalam diri seseorang bahwa setiap tindakannya akan mempunyai pengaruh bagi orang lain maupun bagi dirinya sendiri.

Ruang lingkup pertanggungjawaban notaris meliputi kebenaran materiil atas akta yang dibuatnya. Mengenai tanggung jawab notaris yang berhubungan dengan kebenaran materiil, dibedakan menjadi empat poin, yakni ${ }^{17}$ tanggung jawab notaris secara perdata terhadap kebenaran materiil terhadap akta yang dibuatnya; tanggung jawab notaris secara pidana terhadap kebenaran materiil dalam akta yang dibuatnya; tanggung jawab notaris berdasarkan UUJN terhadap kebenaran materiil dalam akta

16 Gustav Radbruch, Gesetzliches Unrecht und Ubergesetzliches Recht (1946), sebagaimana dikutiip Sudikno Mertokusumo, Teori Hukum, Universitas Atma Jaya, Yogyakarta, 201l, hlm. 23.

17 Abdul Ghofur, Lembaga Kenotariatan Indonesia: Perspektif Hukum dan Etika, UII Press, Yogyakarta, 2009, hlm. 34 . 
yang dibuatnya dan tanggung jawab notaris dalam menjalankan tugas jabatannya berdasarkan kode etik notaris.

Berkaitan dengan tanggung jawab notaris secara perdata terhadap kebenaran materiil terhadap akta yang dibuatnya dapat dilihat dari konstruksi perbuatan melawan hukum yang dilakukan oleh notaris. Pertanggungjawaban atas perbuatan seseorang biasanya praktis baru ada arti apabila orang itu melakukan perbuatanperbuatan yang tidak diperbolehkan oleh hukum. Sebagian besar perbuatan-perbuatan seperti ini merupakan suatu perbuatan yang di dalam KUH Perdata dinamakan perbuatan melawan hukum. Perbuatan melawan hukum diatur pada Pasal 1365 KUH Perdata, bahwa tiap perbuatan melanggar hukum, yang membawa kerugian kepada orang lain, mewajibkan orang yang karena salahnya menerbitkan kerugian itu, mengganti kerugian tersebut.

Notaris hanya sekedar bertanggung jawab terhadap formalitas dari suatu akta otentik dan tidak terhadap materi akta otentik tersebut. Hal ini mewajibkan notaris untuk bersikap netral dan tidak memihak serta memberikan semacam nasihat hukum bagi klien yang meminta petunjuk hukum pada notaris yang bersangkutan. Sejalan dengan hal tersebut, notaris dapat dipertanggungjawabkan atas kebenaran materiil suatu akta bila nasihat hukum yang diberikannya ternyata di kemudian hari merupakan suatu yang keliru. Melalui konstruksi penjelasan UUJN dapat ditarik kesimpulan bahwa notaris dapat dimintai pertanggungjawaban atas kebenaran materiil suatu akta yang dibuatnya bila ternyata ia tidak memberikan akses mengenai suatu hukum tertentu yang berkaitan dengan akta yang dibuatnya sehingga salah satu pihak merasa tertipu atas ketidaktahuannya. ${ }^{18}$

Tanggung jawab notaris secara pidana berkaitan dengan perbuatan yang dilarang di dalam suatu aturan hukum di mana larangan tersebut disertai pula dengan sanksi atau ancaman yang berupa sanksi pidana tertentu bagi yang melanggar. Ketentuan pidana tidak diatur dalam UUJN, tetapi secara tanggung jawab pidana, seorang Notaris/PPAT yang melakukan perbuatan pidana dapat dikenakan sanksi terhadap Notaris/PPAT tersebut. Di dalam UUJN, hanya mengatur sanksi atas pelanggaran yang dilakukan Notaris/PPAT yang berupa akta yang dibuat tidak memiliki kekuatan otentik atau hanya memiliki kekuatan pembuktian sebagai akta di bawah tangan. Sedangkan terhadap Notaris/PPAT, dapat diberikan sanksi berupa teguran sampai pemberhentian dengan tidak hormat.

Jika dikaitkan dengan aspek tindak pidana formal yang dilakukan oleh Notaris/PPAT, dalam keadaan sadar seseorang juga dapat melakukan perbuatan yang merupakan perbuatan terlarang, maka harus ada unsur kesalahan dari pelaku tindak pidana, yaitu kesengajaan (opzet) dan kealpaan (culpa). Kesengajaan (opzet) merupakan hal yang terjadi pada sebagian besar tindak pidana. Biasanya diajarkan bahwa

18 Ima Erlie Yuana, Tanggung Jawab Notaris setelah Berakhir Masa Jabatannya terhadap Akta yang Dibuatnya Ditinjau dari Undang-Undang Nomor 30 Tahun 2004 tentang Jabatan Notaris, Jurnal Hukum Universitas Diponegoro Semarang, 2010, Thesis. 
kesengajaan itu ada 3 (tiga) macam, yaitu ${ }^{19}$ kesengajaan yang bersifat suatu tujuan untuk mencapai sesuatu (opzet als oogmerk); kesengajaan yang bukan mengandung suatu tujuan, melainkan disertai keinsyafan bahwa suatu akibat pasti akan terjadi (opzet bij zekerheidsbewustzijn) dan kesengajaan tetapi dengan disertai keinsyafan hanya ada kemungkinan (bukan kepastian) bahwa suatu akibat akan terjadi (opzet bij mogelijkheidsbewustzijn).

Tanggung jawab notaris secara adminstrasi berkaitan dengan notaris dikenakan sanksi administrasi oleh Majelis Pengawas apabila notaris melanggar ketentuan Pasal 17 ayat 1 UUJN. Sebagaimana sanksi atas pelanggaran yang dilakukan notaris dapat dikenakan sanksi berupa teguran lisan, teguran tertulis, pemberhentian sementara, pemberhentian dengan hormat dan pemberhentian dengan tidak hormat.

Tanggung jawab notaris secara kode etik notaris dapat dilihat dari adanya pelanggaran terhadap kode etik notaris sehingga dapat merusak citra, harkat dan martabat notaris sebagai pejabat pembuat akta otentik. Kode etik notaris merupakan suatu kaidah moral yang ditentukan oleh perkumpulan Ikatan Notaris Indonesia (INI) berdasarkan Keputusan Kongres Perkumpulan dan/atau yang ditentukan dan diatur dalam peraturan perundang-undangan yang mengatur tentang hal itu. Kode etik notaris berlaku bagi serta wajib ditaati oleh setiap anggota perkumpulan dan setiap orang yang menjalankan tugas dan jabatan sebagai notaris. Dalam pembuatan akta, notaris dalam menjalankan tugasnya harus bertindak berdasarkan etika. Etika yang dimaksud adalah kode etik yang untuk menjalankan suatu profesi supaya betul-betul mencerminkan pekerjaan profesional, bermoral, dengan motivasi dan berorientasi pada keterampilan intelektual dengan argumentasi rasional dan kritis. ${ }^{20}$

Terlepas dari tanggung jawab notaris, hukum sendiri memberikan batas batas mengenai tanggung jawab notaris sehingga tidak semua kerugian dibebankan pada notaris. Mengenai ketentuan yang mengatur batas tanggung jawab notaris dapat dilihat pada Pasal 65 UUJN bahwa Notaris, Notaris Pengganti, Notaris Pengganti Khusus dan Pejabat Sementara Notaris bertanggung jawab pada setiap akta yang dibuatnya meskipun protokol notaris telah diserahkan atau dipindahkan kepada pihak penyimpan protokol notaris. ${ }^{21}$

Suatu akta notaris yang dibuat oleh notaris dapat berakibat batal demi hukum. Sebagai pejabat umum, notaris mempunyai tanggung jawab terhadap akta yang telah dibuatnya tersebut. Apabila akta yang dibuat notaris dikemudian hari mengandung sengketa maka hal ini perlu dipertanyakan, apakah akta ini merupakan kesalahan notaris atau kesalahan para pihak yang tidak mau jujur dalam memberikan keterangannya terhadap notaris. Adapun contohnya seperti adanya kesepakatan yang telah dibuat antara notaris dengan salah satu pihak yang menghadap sehingga merugikan pihak lainnya. Jika akta yang dibuat otaris mengandung cacat hukum yang

19 Wirjono Prodjodikoro, Asas-Asas Hukum Pidana di Indonesia, Refika Aditama, Bandung, 20ll, hlm. 65.

20 G.H.S Lumban Tobing, supra note., hlm. 48.

21 Pitlo dalam buku M. Isa Arief, Pembuktian dan Daluarsa Menurut Kitab UndangUndang Hukum Perdata Belanda, PT. Intermasa Jakarta,, 1986), hlm. 51. 
terjadi karena kesalahan notaris baik karena kelalaiannya maupun karena kesengajaan notaris itu sendiri maka notaris dapat dimintakan pertanggungjawaban.

Mengenai persoalan pertanggungjawaban pejabat menurut Kranenburg dan Vegtig ada dua teori yang melandasinya, diantaranya ${ }^{22}$ Teori Fautes Personalles, yaitu teori yang menyatakan bahwa kerugian terhadap pihak ketiga dibebankan kepada pejabat yang karena tindakannya itu telah menimbulkan kerugian. Dalam teori ini beban tanggung jawab ditujukan pada manusia selaku pribadi. Teori Fautes de Services, yaitu teori yang menyatakan bahwa kerugian terhadap pihak ketiga dibebankan pada instansi dari pejabat yang bersangkutan. Menurut teori ini tanggung jawab dibebankan kepada jabatan. Dalam penerapannya, kerugian yang timbul itu disesuaikan pula apakah kesalahan yang dilakukan itu merupakan kesalahan berat atau kesalahan ringan, di mana berat dan ringannya suatu kesalahan berimplikasi pada tanggung jawab yang harus ditanggung.

Berkaitan dengan permasalahan tentang tanggung jawab notaris terhadap akta otentik yang berakibat batal demi hukum yang dibuatnya maka berdasarkan Teori Fautes Personalles maka notaris bertanggung jawab secara perorangan terhadap akta yang dibuatnya.

Pada karakteristik diangkat dan diberhentikan oleh Kemenkumham, menggambarkan bahwa seorang notaris merupakan suatu jabatan. Karakteristik lain dari notaris sebagai pejabat umum yaitu tidak menerima gaji ataupun pensiun dari yang mengangkatnya, hal ini menggambarkan bahwa notaris dalam menjalankan tugas jabatannya adalah seorang diri (individual) dan bukan merupakan bawahan dari pemerintah. Apabila seseorang telah tidak menjabat sebagai notaris. Protokol notaris telah diserahkan kepada notaris penerima protokol, apabila terjadi sengketa terhadap akta di kemudian hari maka yang bertanggung jawab bukan penerima protokol, melainkan notaris tersebut. Hal ini dapat dilihat pada ketentuan Pasal 65 UUJN. Selain mengacu pada teori Kranenburg dan Vegtig tersebut.

Ketentuan Pasal 65 UUJN terkait batasan waktu pertanggungjawaban masih belum jelas. Sebab dalam Pasal 65 UUJN No. 30 Tahun 2004 Jo UUJN No. 2 Tahun 2014 tidak dijelaskan secara tegas, sehingga sampai saat ini notaris memberikan penafsiran bahwa ia bertanggung jawab terhadap akta yang dibuat walaupun telah berhenti menjabat harus bertanggung jawab seumur hidup. Notaris melakukan kesalahan secara pribadi dalam pembuatan akta autentik yang tidak sesuai dengan ketentuan-ketentuan yang telah diatur di dalam UUJN No. 30 Tahun 2004 Jo UUJN No. 2 Tahun 2014 sehingga mengakibatkan terjadinya kerugian bagi para pihak atas pembuatan akta tersebut maka notaris dapat digugat ke pengadilan untuk membayar biaya ganti rugi dan bunga terhadap notaris tersebut. Penuntutan biaya ganti rugi berikut bunga dapat diajukan oleh para penghadap yang merasa dirugikan tersebut ke pengadilan dengan menggunakan ketentuan Pasal 1365 KUH Perdata yang menyebutkan bahwa tiap perbuatan melanggar hukum yang membawa kerugian

22 Ridwan H.R., Hukum Administrasi Negara, Raja Grafindo Persada, Jakarta, 2006, hlm. 365. 
kepada orang lain mewajibkan orang tersebut karena kesalahannya menerbitkan kerugian itu mengganti kerugian tersebut.

Dalam hal notaris telah meninggal dunia, menurut Endang Sri Kawuryan yang menyatakan bahwa ${ }^{23}$ dengan tidak adanya kejelasan mengenai batasan tanggung jawab notaris ini, risiko pekerjaan notaris itu menjadi lebih berat, jika tersangkut masalah pidana Ia akan dibayang-bayangi sanksi pidana sampai mati. Sedangkan untuk tanggungjawab yang sifatnya perdata, para ahli waris si notaris bisa terbawa bertanggungjawab. Dalam suatu keadaan di mana muncul tuntutan oleh pihak yang merasa dirugikan kepada notaris yang meninggal dunia akibat dari akta yang dibuatnya. Apabila masa tuntutan tersebut tidak melewati batas daluwarsa dalam suatu hukum perdata dan selama tuntutan tersebut memperoleh kekuatan hukum tetap maka kewajiban menganti kerugian pihak sebagai penghadap dalam membuat akta notaris dapat dialihkan kepada ahli warisnya.

Menurut J. Satrio dinyatakan bahwa ${ }^{24}$ warisan adalah kekayaan yang berupa kompleks aktiva dan pasiva si pewaris yang berpindah kepada para ahli waris. Jadi jika seseorang menerima warisan dari pewaris, maka tidak hanya hartanya yang ia terima, tetapi ia juga harus memikul utang pewaris. Sehingga menurut teori kewarisan yang menjadi obyek dari harta waris adalah harta kekayaan. Perbuatan melawan hukum yang beraitan dengan jabatan dari pewaris merupakan perbuatan salah yang dilakukan oleh individu, sehingga tidak bisa dikaitkan dengan ahli warisnya. Obyek yang dapat diwariskan hanyalah berupa harta kekayaan dalam arti aktiva dan passiva, perbuatan melawan hukum tidak masuk kategori warisan dalam hukum perdata.

Berdasarkan putusan hakim Nomor : 440/PDT.G/2013/PN.JKT.PST antara Lavina dan Yasphal sebagai Penggugat melawan Harta Kapoor sebagai tergugat dan Notaris Anasrul Jambi, S.H., sebagai turut tergugat. Kronologi kasus tersebut, bahwa pada tanggal 20 Mei 1992 dibuat dan disahkan suatu Akta Hibah No. 141 dan Surat Kuasa Menjual No. 142 oleh Notaris Anasrul Jambi Letter of Statement tertanggal 14 Oktober 1992 yang dibuat dan disahkan oleh Notaris Anasrul Jambi, S.H., di Jakarta yang pada intinya menyatakan bahwa Almarhumah Kamla Rani Sibal membenarkan bahwa dirinya lumpuh sehingga tidak dapat memberikan tanda tangan sehingga hanya dapat memberikan cap jempol tangan kirinya.

Penggugat meragukan kebenaran mengenai dokumen-dokumen tersebut yang diindikasi bertujuan untuk menghilangkan hak-hak ahli waris. Adapun obyek yang menjadi hibah merupakan harta warisan dari para penggugat, sehingga penggugat yang merasa dirugikan mengajukan gugatan kepada terguggat beserta turut tergugat pada tahun 2013. Sedangkan Notaris Anasrul Jambi diketahui sekitar tahun 2006 telah meninggal dunia dan protokol-protokol dipegang oleh notaris pengganti.

Dalam perkara tersebut hakim memberikan putusan bahwasanya dokumendokumen yang dibuat dan disahkan oleh Notaris Anasrul sehubungan dengan harta

23 Yeni Rachman, Limitasi Pertanggungjawaban Notaris terhadap Akta yang Dibuatnya, Jurnal Ilmu Hukum Universitas Brawijaya, 2015, Thesis.

24 Ibid. 
waris batal demi hukum sehingga perbuatan hukum hibah batal demi hukum. Dalam pertimbangan hakim menimbang bahwa oleh karena turut tergugat bertindak selaku notaris dari tergugat, maka secara hukum turut tergugat ikut bertanggung jawab atas kerugian yang dialami oleh para penggugat. Wajar apabila turut tergugat ikut dihukum untuk tunduk dan patuh pada isi putusan.

Meskipun dalam putusan hakim tidak disebutkan secara langsung dari pihak turut terguggat yang harus ikut andil dalam mengganti kerugian kepada pihak penggugat. Kenyataannya, notaris tersebut telah meninggal dunia, maka ahli waris dari turut tergugat yaitu Notaris Anasrul Jambi, S.H., bertanggung jawab untuk turut andil mengganti kerugian bersama tergugat kepada pihak yang dirugikan karena kedudukannya sebagai ahli waris. Pasal 65 UUJN terhadap pembatasan tanggung jawab notaris setalah purna tugas, baik karena pensiun maupun meninggal dunia terhadap akta yang dibuatnya menimbulkan kekaburan norma dalam UUJN. Kekaburan yang dimaksud adalah tidak dijelaskan mengenai batas waktu tanggung jawab notaris setelah berakhir masa jabatan, sehingga sampai saat ini memaknai bahwa notaris bertanggung jawab terhadap akta yang dibuat walaupun telah berhenti menjabat harus bertanggung jawab seumur hidup.

\section{KESIMPULAN}

Berdasarkan hasil penelitan, tanggung jawab dari seorang notaris berakhir ketika dia meninggal dunia dan tidak bisa diwariskan kepada ahli warisnya maupun kepada notaris pemegang protokol notaris. Pertama, didasarkan pada teori fautes personalles ${ }^{25}$, yaitu teori yang menyatakan bahwa kerugian terhadap pihak ketiga dibebankan kepada pejabat yang karena tindakannya itu telah menimbulkan kerugian. Dalam teori ini beban tanggung jawab ditujukan pada manusia selaku pribadi, maka notaris bertanggung jawab secara perorangan terhadap akta yang dibuatnya. Kedua, menurut teori kewarisan yang menjadi obyek dari harta waris adalah harta kekayaan. Perbuatan melawan hukum merupakan perbuatan salah yang dilakukan oleh individu, sehingga tidak bisa dikaitkan dengan ahli warisnya. Obyek yang dapat diwariskan hanyalah warisan berupa harta kekayaan dalam arti aktiva dan passiva, perbuatan melawan hukum tidak masuk kategori warisan dalam hukum perdata.

Dengan demikian, dapat disimpulkan bahwa notaris dalam menjalankan tugas jabatannya tidak luput dari kesalahan, baik yang disengaja maupun yang tidak disengaja. Kesalahan yang dilakukan notaris tersebut memungkinkan notaris berurusan dengan pertanggungjawaban secara hukum, baik secara perdata, pidana, administratif maupun kode etik. Tanggung jawab dari seorang notaris berakhir ketika dia meninggal dunia dan tidak bisa diwariskan kepada ahli warisnya maupun dibebankan kepada notaris pengganti selaku pemegang protokol notaris. Hal ini didasarkan pada argumentasi hukum sebagai berikut. Pertama, berdasarkan teori fautes personalles, yaitu teori yang menyatakan bahwa kerugian terhadap pihak ketiga dibebankan kepada

25 Ridwan H.R., supra note 22., hlm. 365. 
pejabat yang karena tindakannya itu telah menimbulkan kerugian. Dalam teori ini beban tanggung jawab ditujukan pada manusia selaku pribadi, maka Notaris bertanggung jawab secara perorangan terhadap akta yang dibuatnya. Kedua, menurut teori kewarisan yang menjadi obyek dari harta waris adalah harta kekayaan. Perbuatan melawan hukum sebagai akibat dari jabatan Pewaris merupakan perbuatan salah yang dilakukan oleh individu, sehingga tidak bisa dikaitkan dengan ahli warisnya. Obyek yang dapat diwariskan hanyalah berupa harta kekayaan dalam arti aktiva dan pasiva.

\section{DAFTAR PUSTAKA}

Abdul Ghofur, 2009, Lembaga Kenotariatan Indonesia: Perspektif Hukum dan Etika, UII Press, Yogyakarta.

Djoko Sukisno, 2008, Pengambilan Fotocopy Minuta Akta dan Pemanggilan Notaris (Mimbar Hukum vol. 20 nomor 1$)$.

G.H.S Lumban Tobing, 1996, Peraturan Jabatan Notaris, Cetakan Ketiga, Erlangga, Jakarta.

Gustav Radbruch, 2011, Gesetzliches Unrecht und Ubergesetzliches Recht (1946), sebagaimanadikutiip Sudikno Mertokusumo, Teori Hukum, Universitas Atma Jaya, Yogyakarta.

Herlien Budiono, 2005, Pertanggungjawban Notaris Berdasarkan Undang-Undang No. 30 Tahun 24 (Dilema Notaris diantara Negara, Masyarakat dan Pasar", Renvoi, Jakarta.

J. Satrio, 1996, Hukum Perikatan tentang Hapusnya Perikatan Bagian 2, PT. Citra Aditya Bakti, Bandung.

Marthalena Pohan, 1985, Tanggung Gugat Advokad Dokter dan Notaris, Bina Ilmu, Surabaya.

Mochtar Kusumaatmadja, Fungsi dan Perkembangan Hukum dalam Pembangunan Nasional,

Lembaga Penelitian Hukum dan Kriminologi Fakultas Hukum Universitas Padjararan, Penerbit Bina Cipta, Bandung.

Muhammad Yahya Harahap, 1986, Segi-segi Hukum Perjanjian, Alumni, Bandung.

Pitlo dalam buku M. Isa Arief, 1986, Pembuktian dan Daluarsa menurut Kitab UndangUndang Hukum Perdata Belanda, PT. Intermasa, Jakarta.

R. Subekti, 2005, Hukum Perjanjian, Intermasa, Jakarta.

Retnowulan Sutantio dan Iskandar Oerip Kartawinata, 1995, Hukum Acara Perdata dalam Teori dan Praktek, Mandar Maju, Bandung.

Ridwan H.R., 2006, Hukum Administrasi Negara, Raja Grafindo Persada, Jakarta.

Taufik Makarao, 2004, Pokok-pokok Hukum Acara Perdata, PT. Rineka Cipta, Jakarta.

Wawan Tunggal Alam, 2001, Hukum Bicara Kasus-kasus dalam Kehidupan Sehari-hari, Milenia Populer, Jakarta.

Wirjono Prodjodikoro, 2011, Asas-Asas Hukum Pidana di Indonesia, Refika Aditama, Bandung. 
Yahya Harahap, Pembahasan, 2000, Permasalahan dan Penerapan KUHAP: Pemeriksaan Sidang Pengadilan, Banding, Kasasi, dan Peninjauan Kembali, Sinar Grafika, Jakarta

Ima Erlie Yuana, 2010, Tanggung Jawab Notaris Setelah Berakhir Masa Jabatannya Terhadap Akta Yang Dibuatnya Ditinjau Dari Undang-Undang Nomor 30 Tahun 2004 tentang Jabatan Notaris, Jurnal Hukum Universitas Diponegoro Semarang, Thesis

Yuli Kristina, 2015, Analisis Yuridis terhadap Akta Notaris yang Dicatat dalam Sela-Sela Kosong Di Antara Akta Notaris yang Telah Dicatat Dalam Buku Daftar Akta Notaris, Jurnal Hukum Universitas Brawijaya, Thesis

Yeni Rachman, 2015, Limitasi Pertanggungjawaban Notaris Terhadap Akta yang Dibuatnya, Jurnal Ilmu Hukum Universitas Brawijaya, Thesis 
358 | Pertanggungjawaban Ahli Waris Notaris Sebagai Pejabat Umum atas Akta Notaris sebagai Pejabat Umum ...

This page is intentionally left blank 